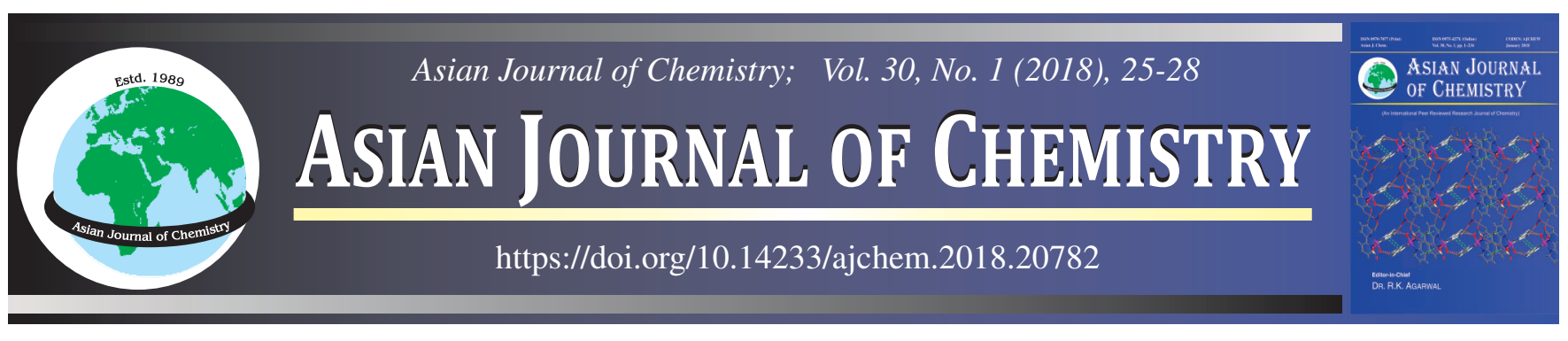

\title{
Preparation and Characterization of Montmorillonite-Cetyl Trimethylammonium Bromide
}

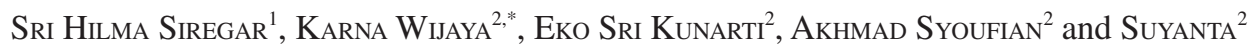

\begin{abstract}
${ }^{1}$ Department of Chemistry, Faculty of Mathematics \& Natural Science, Muhammadiyah Riau University, Pekanbaru, Indonesia ${ }^{2}$ Department of Chemistry, Faculty of Mathematics \& Natural Science, Gadjah Mada University, Yogyakarta, 55281, Indonesia

*Corresponding author: E-mail: karnagmu@gmail.com; karnawijaya@ugm.ac.id
\end{abstract}

\begin{abstract}
The research was focused on the modification of natural montmorillonite by using cationic surfactant cetyl trimethylammonium bromide (CTAB). The natural bentonite was washed with distilled water to clean the impurites of nature bentonite in order to get the montmorillonite fraction. A variation of the amount of CTAB, which is used for the preparation of organo-montmorillonite is $0.5 ; 1.0 ; 1.5 ; 2.0 ; 2.5 \mathrm{CEC}$ of montmorillonite. The organically intercalated montmorillonite composites were characterized by FT-IR, XRD, Brunauer-Emmett-Teller (BET) surface area techniques and SEM-EDX-Mapping methods. The effect of addition of CTAB on the basal spacing of montmorillonite was observed with XRD, indicating an increase in basal spacing $\left(\mathrm{d}_{001}\right)$ of montmorillonite $14.671(2 \theta=6.02)$ to $19.153 \AA\left(4.61^{\circ}\right)$. The main bands of untreated montmorillonite at $3626 \mathrm{~cm}^{-1}$ attributed to stretching vibration of structural hydroxyl groups $(-\mathrm{OH})$ and $1041 \mathrm{~cm}^{-1}$ assigned to Si-O stretching vibration. The spesific bands of organo montmorillonite which appeared at 2924 and $2854 \mathrm{~cm}^{-1}$ are corresponding to stretching asymmetric vibration $v_{\text {as }}\left(\mathrm{CH}_{2}\right)$ and stretching symmetric $\mathrm{v}_{\mathrm{s}}\left(\mathrm{CH}_{2}\right)$, respectively. The $\mathrm{C}-\mathrm{H}$ stretch of CTA ${ }^{+}$structure in-plane binding was noticed at $1473 \mathrm{~cm}^{-1}$. The bands at 516 and $462 \mathrm{~cm}^{-1}$ were assigned to the Al-O-Si (octahedral layer) bend for untreated and organo-montmorillonite, respectively. The BET specific surface area reduced with increasing surfactant concentrations.
\end{abstract}

Keywords: Montmorillonite, Surfactant cationic, Organo-montmorillonite.

\section{INTRODUCTION}

Indonesia has natural mineral resources that are abundant in some provinces with large enough amounts, one of the mineral is bentonite. Mineral bentonite has a diameter less than $2 \mu \mathrm{m}$, which consists of a wide variety of phyllosilicate minerals containing silica, aluminum oxide and hydroxide which can bind to the primary air. The composition of bentonite is the mineral montmorillonite $(85 \%)$ and other impurities such as quartz, illite, calcite and chlorite. Montmorillonite structure consists of three layers: one layer of octahedral shaped alumina in the middle flanked by two layers of silica $\left(\mathrm{SiO}_{4}\right)$ tetrahedral shape. There are monovalent and bivalent cations such as $\mathrm{Na}^{+}, \mathrm{Ca}^{2+}$ and $\mathrm{Mg}^{2+}$ among the octahedral and the tetrahedral layers. This arrangement causes the formation of interior space and charge interlayer [1-3]. It also provides two different sections within the layer of negatively charged clay which is insoluble in water and the cations electrostatically attached to the lining of the micelles. It is therefore natural clay act as ion exchangers, sorption or adsorben molecular sieves and catalysts. Based on the properties of these clay minerals, they have many uses such as nanocomposites, catalysts and adsorbents [4-6]. Clay minerals, basically have the ability to absorb and release water in a reversible manner so that the cations are bound to it and can easily be replaced with other cations from the outside. Referring to the properties owned by natural clay mineral, besides the price is relatively low-cost, clay minerals are highly effective as an adsorbent $[7,8]$.

In this paper, the montmorillonite was organically intercalated by using cetyl trimethylammonium bromide (CTAB) as a modifier agent. Modification of natural bentonite with a surfactant is an easy method to change the nature of the bentonite surface hydrophilic to hydrophobic [9-11]. The negative charge on the surface of the silica layer of bentonite can be attached to the polar compounds and cations in the interlayer of bentonite can be exchanged with organic cations [11-14]. The structure and texture of nature and organically modified montmorillonite were characterized using various methods, such as XRD, FT-IR, SEM-EDX-mapping and surface area measurements along with the chemical analysis.

\section{EXPERIMENTAL}

White bentonite clay collected from Tasikmalaya, Indonesia, was used as primary material. All chemicals used were analytical reagent grade, obtained from the Merck Company. 
Double-ionized water was utilized in all experiments. Double ionized water was used for preparing the solutions and suspensions. X-ray diffraction patterns were obtained at room temperature on a XRD-6000 Shimadzu, using $\mathrm{Cu} \mathrm{K}_{\alpha}$ powder irradiated by the $\lambda=0.5406 \AA$. Fourier transform infrared spectroscopic analysis was conducted on a Shimadzu spectrometer. FT-IR spectra in the transmittance mode were recorded in the range of $4000-400 \mathrm{~cm}^{-1}$ at room temperature using the $\mathrm{KBr}$ disc technique spectrometer. The specific surface area was measured at $77.3 \mathrm{~K}$ by BET method with a Micrometrics Gemini 2360 instrument using $\mathrm{N}_{2}$ gas. The BET specific surface areas were calculated from the adsorption data in the relative pressure $(\mathrm{P} /$ $\mathrm{P} 0$ ). The pore size and pore volume were calculated using the BJH method applied to the desorption leg of the isotherms. The morphology of untreated montmorillonite and organomontmorillonite were observed using a scanning electron microscope (SEM, JEOL, JSM-6510, JED 2300, Analysis Station) and its composition was determined via energy dispersive X-ray (EDX, JEOL, JSM-6510, JED 2300, Analysis Station).

Synthesis of organo montmorillonite with CTAB: The bentonite was prepared and sieved to 250 mesh sizes. A spesific amounts of bentonite were added to the glass beaker, which was already contained $100 \mathrm{~mL}$ aquabidest, then stirred for $24 \mathrm{~h}$. The CTAB with varying concentrations of $(0.5 ; 1.0 ; 1.5$ and 2.0$) \mathrm{x}$ untreated bentonite CEC was added slowly into a glass beaker containing a homogeneous bentonite suspension. The mixture was stirred for $24 \mathrm{~h}$, then dried at $110-120{ }^{\circ} \mathrm{C}$ for $24 \mathrm{~h}$. The synthesized material was crushed and sieved to 250 mesh sizes.

\section{RESULTS AND DISCUSSION}

X-ray diffraction analysis: Characterization with the XRD method was used to see an increase in the distance between the layers of montmorillonite after the formation of organomontmorillonite. The increase in d-spacing indicates the intercalation process in the manufacturing process of montmorillonite layer composites with the inclusion of surfactant in bentonite. Fig. 1 shows the XRD patterns of montmorillonite and organo mont-morillonite samples at indicated multiple of CEC.

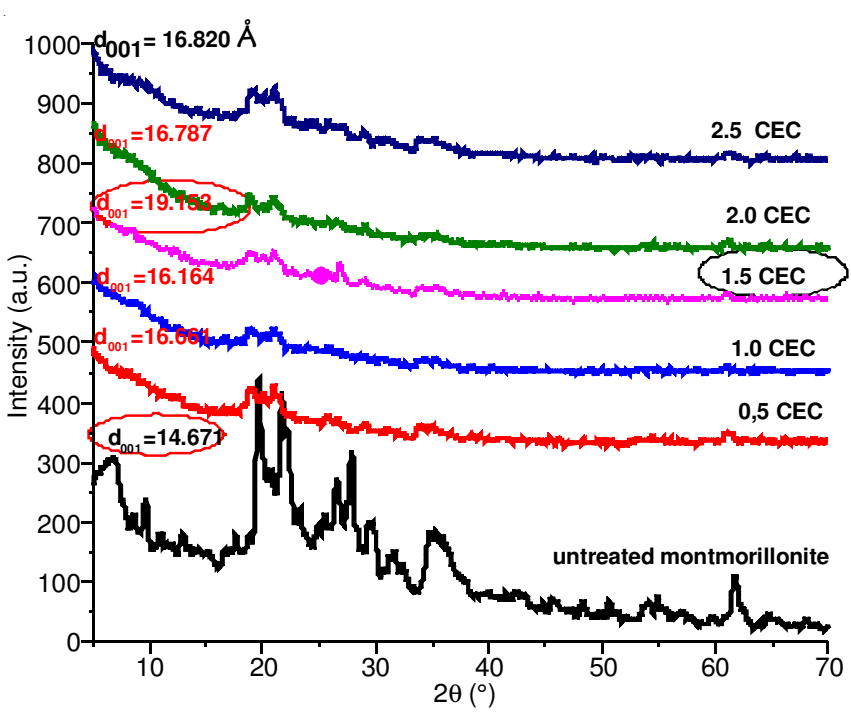

Fig. 1. Comparison of XRD of natural montmorillonite and organo montmorillonite treated with different concentration of CTAB
The natural bentonite samples consisted of predominantly montmorillonite, substantial amounts of quartz and feldspar impurities, in addition to minor amount of illite and gypsum (Fig. 1). The basal spacing of natural montmorillonite found to be $14.671 \AA\left(2 \theta=6.02^{\circ}\right)$. Fig. 1 shows that the relationship between the intercalation dosage and the distance between the crystal layers is evident. At a low concentration of surfactant d-spacing value higher with the value of $\mathrm{d}_{001}=19.153 \AA$ ( $\left.4.61^{\circ}\right)$ than the surfactant concentration much higher. Based on the results of XRD data a shift toward a smaller value. When the $\mathrm{CTA}^{+}$have been entered to the layer of montmorillonite then the $\Delta \mathrm{d}_{001}$ of the interlayer space become $4.392 \AA$. Increasing the concentration of CTAB greatly affect the arrangement of $\mathrm{CTA}^{+}$cations in the montmorillonite interlayer cavity in accordance with the increasing value of basal spacing. Short chain alkyl ammonium ions arranged in a monolayer and long-chain alkyl ammonium ions arranged in a bilayer with alkyl chains parallel to the silicate layers $[15,16]$. The addition of an excessive concentration of surfactant will form the arrangement of different $\mathrm{CTA}^{+}$ions are monolayer, bilayer, pseudo trimolecular layer, paraffin monolayer and bilayer paraffin $[17,18]$. Based on the our results, the arrangements of the intercalated $\mathrm{CTA}^{+}$in the interlayer of montmorillonite was laterally monolayer.

FTIR analysis: The infrared spectra of the natural montmorillonite and the organo-montmorillonite are shown in Fig. 2. It can be seen that there is a major changes of the spectrum of the organic montmorillonite compare to the natural montmorillonite. The strong bands at 2924.09 and $2854.65 \mathrm{~cm}^{-1}$ attributed to asymmetric and symmetric stretching vibrations respectively of C-H groups in cetyl trimethyl ammonium bromide. The absorption peak appearing at about $1473.62 \mathrm{~cm}^{-1}$ belongs to bending vibration of $\mathrm{NH}_{4}{ }^{+}$in the molecules of the organic intercelating agent and their bonding supporting the intercalation of surfactant molecules between the silica layers [19,20]. There is no evident change in the absorption peak of structural water at $3626 \mathrm{~cm}^{-1}$ after montmorillonite is treated by organic intercelating agent but the absorption peaks of interlayer adsorbed water at 3448 and $1635 \mathrm{~cm}^{-1}$ are weakened remarkably. The

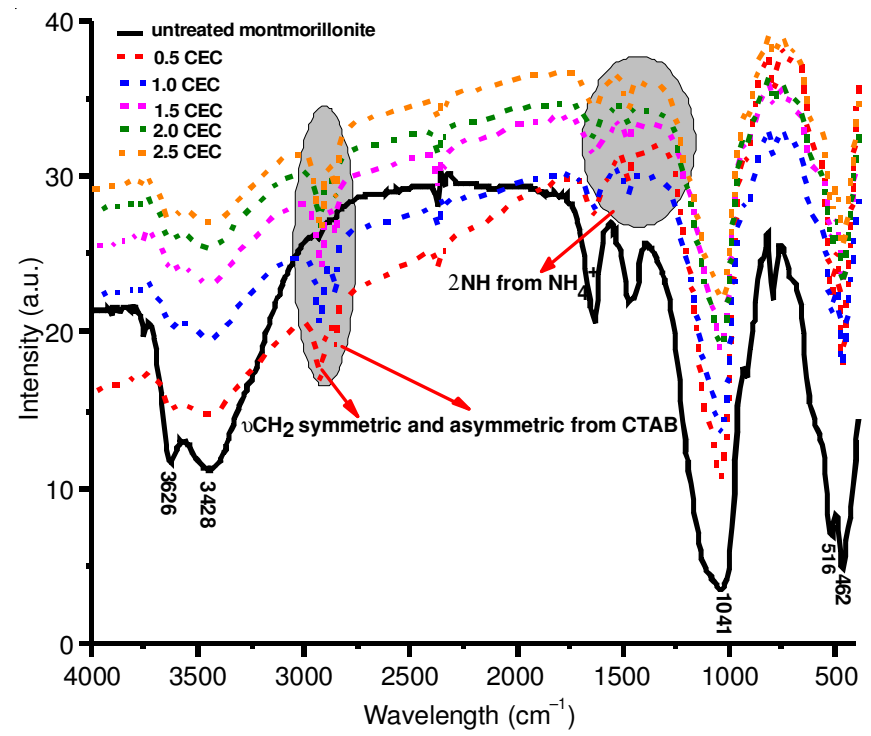

Fig. 2. Comparison of infrared spectra of natural montmorillonite and organo montmorillonite 
attributions of absorption at 1041.56, 918.12, 794.67, 516.92 and $462.92 \mathrm{~cm}^{-1}$ can be due to $\mathrm{Si}-\mathrm{O}-\mathrm{Si}$ and $\mathrm{Si}-\mathrm{O}-\mathrm{Al}$ stretching $[21,22]$. It is suggested that there is considerable amount of CTAB molecules which had been effectively inserted into the montmorillonite interlayers and have no much effect on the crystal lattice of montmorillonite.

SEM-EDX analysis: The SEM examination was carried out to assess the effect of the organo modification on the surface morphology of the montmorillonite. We present representative SEM images of the natural montmorillonite and organomontmorillonite in Fig. 3. SEM was used to probe the change in morphological features after modification with cationic surfactant process. Fig. 3 clearly shows that the morphology of the montmorillonite consists of stacked layers of silicate.

The SEM-EDX analysis of natural and organo-montmorillonite is to determine the ratio of $\mathrm{Si} / \mathrm{Al}$ and $\mathrm{Na} / \mathrm{Si}$. Table-1 shows that there is a montmorillonite organo cation exchanged with $\mathrm{Na}^{+}$as the $\mathrm{CTA}^{+}$cation of cationic surfactant CTAB. The SEM-EDX analysis shows that the most abundant elements are $\mathrm{Si}$ (26.03), $\mathrm{Al}(7.12)$ and $\mathrm{O}(38,40 \%)$, respectively. While, the most abundant compound as well as the main species in the structure of bentonite clay is $\mathrm{SiO}_{2},(55.69), \mathrm{Al}_{2} \mathrm{O}_{3}$ (13.46), $\mathrm{MgO}$ (2.27), $\mathrm{FeO}(2.20 \%)$, respectively.

Elemental analysis of montmorillonite and organo-montmorillonite can be seen from the SEM-mapping. Fig. 3 explains

\begin{tabular}{lccccc}
\multicolumn{5}{c}{ TABLE-1 } \\
\multicolumn{5}{c}{$\begin{array}{c}\text { RATIO Si/Al OF MONTMORILLONITE AND } \\
\text { ORGANO-MONTMORILLONITE }\end{array}$} \\
\cline { 2 - 5 } \multicolumn{1}{c}{ Samples } & $\mathrm{Na}$ & $\mathrm{Si}$ & $\mathrm{Al}$ & $\mathrm{Si} / \mathrm{Al}$ & $\mathrm{Na} / \mathrm{Si}$ \\
& 0.97 & 26.03 & 7.12 & 3.67 & 0.043 \\
\cline { 2 - 5 } Montmorillonite & 0 & 25.52 & 7.22 & 3.53 & 0 \\
\hline Organo-montmorillonite & 0 & & & & \\
\hline
\end{tabular}

that the colours contained in the image have a meaning. The blue colour indicates Fe elements in the form of a cation, the green colour indicate $\mathrm{Mg}$, the red shown the existence of Si elements, while the orange indicates $\mathrm{Al}$. It can be seen that $\mathrm{Si}$ and $\mathrm{Al}$ are the most dominant elements in the montmorillonite structure.

Surface area measurements: BET measurements were performed to determine the specific surface area of montmorillonite and montmorillonite-CTAB. Table- 2 shows that the CTAB-montmorillonite specific surface area is smaller than the untreated montmorillonite specific surface area. This is due to the CTAB coating to the montmorillonite surface. CTAB binding in the interlayer is also likely to bind to the surface of montmorillonite so that the specific surface area becomes small. The addition of surfactant greater than 1.0 CEC did not provide significant specific surface area increase.

\section{TABLE-2}

BET SPECIFIC SURFACE AREA ( $\mathrm{S}_{\mathrm{BET}}$ ), TOTAL PORE VOLUME $\left(\mathrm{V}_{\text {total }}\right)$, AVERAGE PORE RADIUS (D) FOR UNTREATED MONTMORILLONITE, ORGANO-MONTMORILLONITE WITH CONCENTRATION VARIATION OF CTAB

\begin{tabular}{cccc}
\hline Sample & $\mathrm{S}_{\mathrm{BET}}\left(\mathrm{m}^{2} / \mathrm{g}\right)^{*}$ & $\mathrm{~V}_{\text {total }}\left(\mathrm{cm}^{3} / \mathrm{g}\right)^{* *}$ & $\mathrm{D}(\AA)$ \\
\hline Montmorillonite & 54.821 & 0.696 & 17.795 \\
$0.5 \mathrm{CEC}$ & 14.003 & 0.233 & 17.804 \\
1.0 CEC & 18.110 & 0.068 & 20.963 \\
1.5 CEC & - & 0.877 & 19.498 \\
2.0 CEC & 12.208 & 0.119 & 19.727 \\
2.5 CEC & 32.366 & 0.135 & 16.870 \\
\hline "Determined by the multipoint BET method. \\
** Determined using BJH pore analysis.
\end{tabular}

It is interesting to note that the BET specific surface area of the $1.5 \mathrm{CEC}$ can not be detected because the organic ions had been intercalated into the interlayer spaces. At 1.0 CEC,
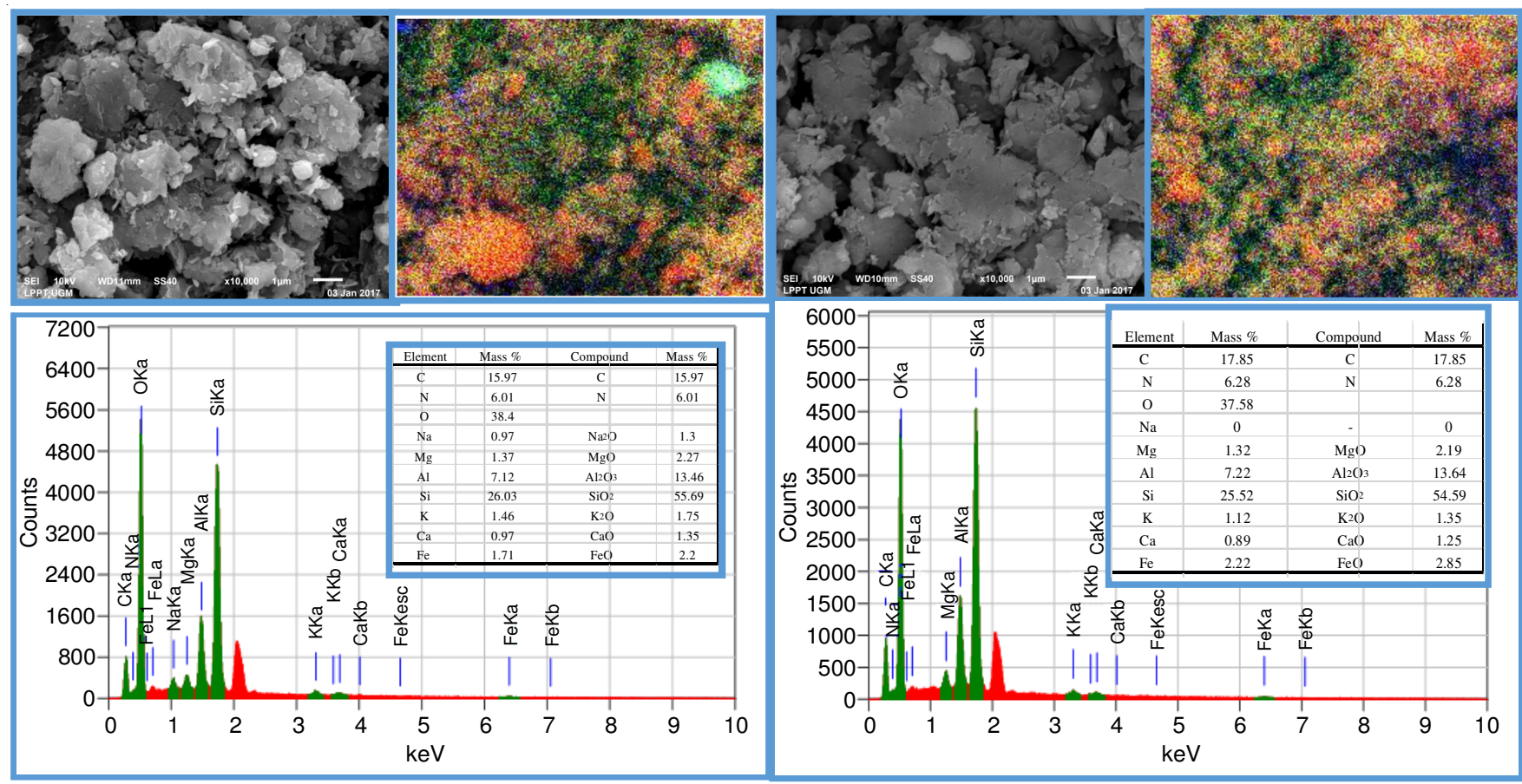

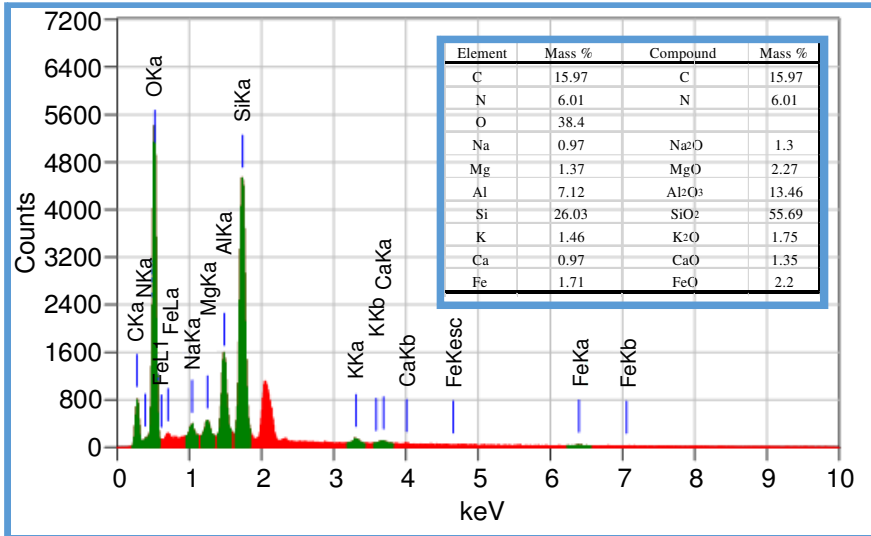

(a) (b)

Fig. 3. SEM-EDX spectra of natural montmorillonite and organo montmorillonite, (a) Natural montmorillonite: 1. SEM images, 2. Mapping, 3. EDX (b). Organo montmorillonite: 1. SEM images, 2. Maping, 3. EDX 
the specific surface area increased and reduced at 1.5 up to 2.0 CEC, but increased again at 2.5 CEC.

\section{Conclusion}

Montmorillonite was successfully modified by surfactant cationic CTAB (1.5 CEC of montmorillonite). The obtained results indicated that the $\mathrm{CTAB}$ modifier can be considered as the most suitable modifier for the modification of the natural bentonite. The introduction of $\mathrm{CTA}^{+}$ions results in the substantial modification hydrophilic surface properties of silicates to strongly organophilic. An increase in the value $\mathrm{d}_{001}(19.153$ into 14 . $671 \AA$ A) and a shift angle 2 theta of montmorillonite and organo montmorillonite namely $\left(2 \theta=4.61-6.02^{\circ}\right)$ indicates the success of the intercalation of surfactant molecules in the region between layers montmorillonite. Surfactant molecules not only entering the space between layers of montmorillonite, but also dispersed outside of the space between the layers. The BET specific surface area of untreated montmorillonite and CTAB-montmorillonite decreases in the order:

\section{Montmorillonite $>2.5$ CEC CTAB $>1.0$ CEC CTAB $>$} 0.5 CEC CTAB > 2.0 CEC-CTAB > 1.5 CEC CTAB

\section{ACKNOWLEDGEMENTS}

The authors thank University of Muhammadiyah Riau and University of Gadjah Mada for providing the research facilities.

\section{REFERENCES}

1. J. Hua, Appl. Clay Sci., 114, 239 (2015); https://doi.org/10.1016/j.clay.2015.06.005.

2. M.E. Parolo, G.R. Pettinari, T.B. Musso, M.P. Sánchez-Izquierdo and L.G. Fernández, Appl. Surf. Sci., 320, 356 (2014); https://doi.org/10.1016/j.apsusc.2014.09.105.

3. C. Bilgic, D.T. Yazici, N. Karakehya, H. Cetinkaya, A. Singh and M.M. Chehimi, Int. J. Adhes. Adhes., 50, 204 (2014); https://doi.org/10.1016/j.ijadhadh.2014.01.033.

4. A.M. Motawie, M.M. Madany, A.Z. El-Dakrory, H.M. Osman, E.A. Ismail, M.M. Badr, D.A. El-Komy and D.E. Abulyazied, Egypt. J. Pet., 23, 331 (2014); https://doi.org/10.1016/j.ejpe.2014.08.009.

5. L. Yaming, B. Mingliang, W. Zhipeng, L. Run, S. Keliang and W. Wangsuo, J. Taiwan Inst. Chem. Eng., 62, 104 (2016); https://doi.org/10.1016/j.jtice.2016.01.018.
6. H. Zaghouane-Boudiaf and M. Boutahala, Adv. Powder Technol., 22, 735 (2011); https://doi.org/10.1016/j.apt.2010.10.014

7. V.K. Gupta, M. Sharma and R.K. Vyas, J. Environ. Chem. Eng., 3, 2172 (2015); https://doi.org/10.1016/j.jece.2015.07.022.

8. Y. Utubira and K. Wijaya, Int. J. Chemtech Res., 9, 475 (2016).

9. R. Koswojo, R.P. Utomo, Y.H. Ju, A. Ayucitra, F.E. Soetaredjo, J. Sunarso and S. Ismadji, Appl. Clay Sci., 48, 81 (2010); https://doi.org/10.1016/i.clay.2009.11.023.

10. C.M. Ouellet-Plamondon, J. Stasiak and A. Al-Tabbaa, Colloids Surf. A Physicochem. Eng. Asp., 444, 330 (2014); https://doi.org/10.1016/j.colsurfa.2013.12.032.

11. N.N.A. Kadir, M. Shahadat and S. Ismail, Appl. Clay Sci., 137, 168 (2017); https://doi.org/10.1016/j.clay.2016.12.025.

12. A. Suseno, K. Wijaya, W. Trisunaryanti and M. Shidiq, Asian J. Chem., 27, 2619 (2015); https://doi.org/10.14233/ajchem.2015.18599.

13. A.K. Rahardjo, J.J.M. Susanto, A. Kurniawan, N. Indraswati and S. Ismadji, J. Hazard. Mater, 190, 1001 (2011); https://doi.org/10.1016/j.jhazmat.2011.04.052.

14. E. Orucoglu and P.A. Schroeder, Appl. Clay Sci., 132-133, 90 (2016); https://doi.org/10.1016/j.clay.2016.05.021.

15. J. Madejová, L. Jankovi, M. Pentrák and P. Komadel, Vib. Spectrosc., 57, 8 (2011).

16. G. Zhuang, Z. Zhang, H. Wu, H. Zhang, X. Zhang and L. Liao, Colloids Surf. A Physicochem. Eng. Asp., 518, 116 (2017); https://doi.org/10.1016/j.colsurfa.2017.01.014.

17. L.A. Ratkievicius, F.J.V.D. Cunha Filho, E.L.D. Barros Neto and V.C. Santanna, Appl. Clay Sci., 135, 307 (2017); https://doi.org/10.1016/j.clay.2016.10.011.

18. B. Aghabarari and N. Dorostkar, J. Taiwan Inst. Chem. Eng., 45, 1468 (2014); https://doi.org/10.1016/j.jtice.2014.03.006.

19. M. Kiranpan, R.D.C. Soltani, A. Hassani, S. Karaca and A. Khataee, J. Taiwan Inst. Chem. Eng., 45, 2565 (2014); https://doi.org/10.1016/j.jtice.2014.06.007.

20. A. Khenifi, B. Zohra, B. Kahina, H. Houari and D. Zoubir, Chem. Eng. J., 146, 345 (2009); https://doi.org/10.1016/j.cej.2008.06.028.

21. S.S. Metwally and R.R. Ayoub, Appl. Clay Sci., 126, 33 (2016); https://doi.org/10.1016/j.clay.2016.02.021.

22. C. Wang, X. Jiang, L. Zhou, G. Xia, Z. Chen, M. Duan and X. Jiang, Chem. Eng. J., 219, 469 (2013); https://doi.org/10.1016/j.cej.2013.01.028. 